\title{
Evaluation of Fund for Agricultural Credit Guarantee Scheme in Nigeria: A Tool for Economic Growth and Development
}

\author{
${ }^{1}$ Atagana S. \& ${ }^{2}$ Kalu C. \\ ${ }^{I}$ Department of Economics School of Arts and Social Sciences, College of Education, Ekiadolor, Benin, Nigeria \\ ${ }^{2}$ Department of Forestry and Wildlife Faculty of Agriculture, University of Benin, Benin City, Nigeria
}

\begin{abstract}
Financing agricultural projects had suffered greatly because it was below the desired minimum to support economic growth. Hence, the establishment of Agricultural credit guarantee scheme fund to strengthen the contribution of the sector in economic development. This paper focuses on the effort to make empirical verification on variables like loan guarantee (AC), number of farmers benefited (NF)), Agricultural Produce $(A O)$ and Non-oil export $(O E)$ and their impact on GDP. The results show that variables, such as guaranteed loan, number of benefiting farmers, agricultural produce indicate positive sign and are significant in growth of GDP at 5\% level of significance: The findings reveal that it is imperative to increase the number of farmers' beneficiary to agricultural loan scheme and agricultural produce if visible impact can be made on GDP from the sector. This is because the real sector economy has been neglected in Nigeria at the expense of the oil sector for several decades. Thus, this sector of the economy suffers consistently from overwhelming trade deficit from the international communities.
\end{abstract}

\section{Introduction}

Agricultural finance is one of the services provided by financial institutions especially the commercial banks, and some specialized organs of government such as the Ministry of Agriculture of the various states in Nigeria. The provision of this service is not limited to the aforementioned but also identified are the informal or non institutional lenders i.e. the local thrift collector and cooperative bodies who also provide credit to farmers in the absence of banks in the rural areas. Abe (1982) has reported that non-institutional creditors accounted for $70 \%$ of the total credits received by Nigerian farming population. However, with the present situation in Nigeria these services could hardly meet the increasing demand for credit by farmers. This creates a scenario that predicts a bleak future for the sub-sector at its essential benefits.

Agricultural finance comes in the form of Agricultural credit to farmers for providing wherewithal for various productive activities. According to Adegeye and Dittoh (1985) agricultural credit is the process of obtaining control over the use of money, goods and services for agriculture in the present in exchange for a promise to repay at a future date. The important role of credit in agricultural production and the problems emanating from the lack of it are a major constraint due to the difficulty in receiving it, particularly by the rural farmers that constitute the large number of the farming populace in Nigeria. They tend to suffer largely as a result of limited access to credit resulting from their low level of education, absence of banks in the rural areas and the issue of their subsistence level of production (Ajetombi, et al, 2003).

Consequent upon the aforementioned, the Federal Government of Nigeria was prompted to establish the Agricultural Credit Guarantee Scheme Fund (ACGSF) in 1978 through the Central Bank of Nigeria (CBN). This is indeed a deliberate policy of government meant to ameliorate some of the problems faced by farmers in accessing credit for farming purposes and production. Also, to encourage the lending Banks to support the agricultural sector with the provision of credit. The scheme is an indirect measure taken by government since it only guarantees the agricultural credit provided by the Commercial Banks in the ratio of 60 to 40 percent, in other words, government bears losses up to $60 \%$ arising from failure or inability of the farmers to repay the loan facility due to unforeseen circumstances that may eventually result to bad and doubtful debt, while the banks who are in direct contact with the farmers bear the balance of $40 \%$ loss.

Since the inception of ACGSF, the scheme provides guarantee to large volumes of loans given to farmers throughout Nigeria. Thus, it paves the way for a relative ease of credit accessibility by farmers. On the other hand, farmers are expected to produce to meet the food needs of the country, for export, lower cost of agro-produce and reduce inflation, hence increase Nigeria's foreign earnings as well as diversify its revenue base, for the overall purpose of encouraging economic growth and development. From the fore-going an attempt is made in this paper to investigate the impact of the ACGSF Scheme as a driving force for agricultural development and the growth of he Nigerian economy. 


\section{The Research Issue and Methodology}

One major concern of economists is how to ensure credit delivery to the agricultural sector with minimum difficulties in order to enhance maximum production of all agro-produce. In fact, meaningful agricultural development can only take place if credit is provided to support farmers of both large and small scale (Von-Prisckieke 1986), Farming activities over the years in Nigeria have been seen to be supported by two main sources of credit, i.e. the formal and the informal sources, otherwise referred to as institutional credit sources and non-institutional sources respectively. The informal sources are known to be the major and dominant source of credit particularly to the rural farmer (Abe, 1982). The need to provide formal credit to worthy borrowers has long been identified as the primary function of commercial banks (Reed et al, 1984).

Agricultural development and food availability in a country could be viewed mainly in terms of increasing the volume of annual productivity. This can be stimulated and achieved with the availability of funds for the farmer, particularly, the rural farmers who contribute so much to the overall agricultural output in Nigeria. With increased funding, the rural farmer could increase his arable land cultivation, employ modern farm tools and increase his livestock production.

\section{Empirical Model}

Productivity depicts the level of output of a given firm. In an economy, where most of the industries are operating in almost full installed capacity, their productivity seems to be very high. The indication is that the trend is one of the fundamentals of economic growth.

Productivity Measurement: Total factor productivity according to Prokopenko (1992) is expressed as

$$
\mathrm{Pt}=\frac{Q t}{L+C+R+Q} \quad \ldots \quad \ldots \quad \ldots \quad \ldots \quad \text { equation (1) }
$$

Where

$$
\begin{aligned}
& \mathrm{Pt}=\text { Total Productivity } \\
& \mathrm{Qt}=\text { Output } \\
& \mathrm{L}=\text { Labour input } \\
& \mathrm{C}=\text { Capital input } \\
& \mathrm{R}=\text { Raw material input }
\end{aligned}
$$

$\mathrm{Q}=$ Other miscellaneous goods and services (input factor)

In line with the above, a common approach to the measurement of productivity is to assume a neoclassical production function at the sectoral or industry level (Tybout, 1992) such that:

$$
\begin{array}{llllll}
\mathrm{Y}=\mathrm{f}\left(\mathrm{v}_{1} \mathrm{t}_{1}\right) & \ldots & \ldots & \ldots & \ldots & \text { equation (2) }
\end{array}
$$

That is total factor output is a concave function of the vector of inputs $(\mathrm{Kv})$ and a time index $(\mathrm{t})$ which allows the function to shift with technological innovations or improvements in the efficiency of existing input factors.

In assessing the relative impact of the (ACGSF) in the provision of credit for the development of agriculture and the economy of Nigeria a linear model is posited in line with the neo-classical production function.

The model is presented thus:

$\mathrm{Q}=\mathrm{T}(\mathrm{AG}, \mathrm{NF}, \mathrm{AO}, \mathrm{OE}, \mathrm{AGN}, \mathrm{e}) \quad \ldots \quad \ldots$ equation (3)

Where,

$\mathrm{Q}=$ Gross Domestic Product (GDP)

$\mathrm{AG}=$ Annual Loan Amounts Guaranteed

$\mathrm{NF}=$ Number of Benefiting Farmers

$\mathrm{AO}=$ annual Agric Produce

$\mathrm{OE}=$ Non-oil Export

$\mathrm{e}=$ Error term

In Nigeria, GNP values are often accepted for GDP, reason being that contribution of foreign Nationals to GNP is very small accounting for less than $1 \%$ contribution. In the same vein, GDP is used as an index of development partly because, social progress is accounted with GDP growth. Heavily expenditure by various levels of government on physical infrastructures improve economic welfare of the people and facilitates production of goods and services across every sector of the economy so as to stimulate rapid growth in aggregate output.

\section{Economic Growth and Development}

Economic growth in the past has been held in such a high esteem partly because of the belief that it would help in some ways to solve any problem that might arise in every socio-economic setting (Hamrin 1980). 
It was regarded as a panacea to solve deficit and infrastructural problems. Some decades ago, the public sector spending has been increasing in geometric terms through various government activities and interactions with ministries and agencies (Niloy et al, 2003).

In many ways, growth has become the central purpose of most countries in the world in order to guide social ethics. The modern economic growth is really a post-world war II phenomenon. Simon Kuznets one of the foremost scholars of economic growth has identified five characteristics of modern economic growth:

- High rate of growth of per capita product and of population in developing countries.

- High growth rate of productivity.

- High rate of structural transformation

- Rapid change in the structure of the society and its ideology; and

- Propensity for developing countries to increase power of technology, particularly transport and communication (Kuznets. 1973).

Anyanwu et al, (1997) noted that the growth of economy is derived from the investment and economic activities in such economies. Thus, economic growth is being propelled by the investment which is made possible by investment opportunities such as agricultural enterprises. In the underdeveloped country public expenditure has an active role to play in reducing regional disparities, developing social overheads, recreation of infrastructure of economic growth. This in a large extent explains why Nigeria creates an incentive to encourage prospective investors to be involved in economic activities.

Measurement of economic growth is difficult because of lack of data, differences in the quality of data and lack of comparability of data from different sources (Jumper et al, 1980). However, the measurement can be done in two ways; (Relative and Absolute). Relative growth refers to the rate or percentage of growth of a particular area, industry or service during a particular period of time. On growth of one region or one factor compared with another during the same period of time, while absolute growth refers to the actual number of a particular currency, production units or people during the period. The most commonly available and frequently used to measure economic growth in the world is GNP.

In Nigeria, economic growth is measured either at current factor cost and/or constant factor cost. The latter is preferred in order to ensure that the growth experienced is not due to price increase and inflation factor. Nigeria recorded tremendous increases between 1980 and 1995 in economic growth. Though there was slight decline between 1982 and 1985. An examination of the sectoral contribution to GDP growth reveals that the nation's economic growth was due to agriculture and forestry (Anyanwu et al, 1997). However, long-run growth and development of an economy demands that the economy will be propelled by industries. Thus, every nation is interested in the macro-economic policies focused on the maximization of economic growth.

Economic development on the other hand is a wider concept than economic growth because the former includes economic growth together with a number of other economic phenomena. There are several attempts at arriving at a more embracing definition of economic development which gave rise to series of development decades (Bartelmus, 1994). The first development decade (1960's) was based on the belief that the fruits of accelerated economic growth would trickle down to the low-income population strata (the masses). Since the trickle down effect did not materialize and thus failed to alleviate poverty in developing countries, the issue of social justice was included in the objective of the second development decade. The idea was to prove the distribution of the result of economic growth.

Development decade of the 1980's proceeded from the recognition that the objectives of the second decade were not met because of inequalities and imbalance in interactional economic relations. The forth united development decade admitted that the objectives of the third decade were in most part unattained. The 1980s were characterized as a decade of falling growth rates, declining living standards and deepening poverty with widening gap between the rich and the poor. The latest strategy of the 1990s calls for an acceleration of economic growth, such that addresses the following aspects of development like eradication of poverty and hunger, human resources development and protection of environment.

Todaro (1998) noted that economic development is traditionally meant to be the growth of GNP at rates of between 5 percent and 7 percent for a national economy whose economic condition has been more or less static. Hence, in the past, economic development is typically seen as planned alteration of structure of production and employment so that agriculture share of both decline and that of the manufacturing and/or service industries increase.

The new view of economic development is redefined as an attempt to reduce or eliminate poverty, inequality and unemployment in the growing economy. This is why renowned economists like Todaro, \& Smith, (2003) are of the opinion that there is no economic development when the socio-economic indicators like poverty, inequality, and unemployment exist in the economy even if GNP doubles. As a result,. The challenge of development is to improve the quality of life, especially in the Less Developed Countries (LDCS). In the 
foregoing study the variables were carefully selected to capture the efforts of government at confronting the developmental challenges of the country, particularly the growth of the agricultural sector. This highlights how development policies have faired in meeting the citizens basic need such as food, cloths, housing and other social overheads.

\section{Guaranteed Credit and Economic Development in Nigeria}

Estimation of the model produced the relative impacts of annual loan and other variables on the Gross Domestic Product. Economic development in theory is the interplay of some economic factors. We attempt here to explain the influence of these factors with particular emphasis on the agricultural sector vis-à-vis the provision of guaranteed credit to the growth and development of agriculture.

The total influence of excluded factors (variables) is captured by the autonomous component of the model of economic growth and for the purpose of this study the model is specified as follows:

Where

$$
\mathrm{Q}=\mathrm{C}+\mathrm{aAG}+\mathrm{bNF}+\mathrm{c} A \mathrm{AO}+\mathrm{dOE}+\mathrm{e}) \ldots \quad \ldots \quad \ldots \text { equation (4) }
$$

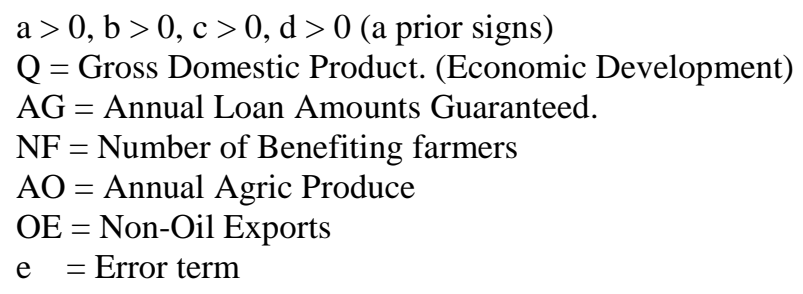

Model (4) exemplifies the typical relationship that exists between the dependent variable and the independent variables, showing a positively related growth in annual loan amount guaranteed and the other variables considered in the foregoing analysis which spanned from 1987 - 2008. The results showed that independent variables explained $98 \%$ of the systematic variation in GDP in the period under review table 1 . Statistically significant variables with correct signs were Annual loans amount guaranteed, Number of benefiting farmers and Annual agricultural produce.

Table 1: Estimation: Reults Of Model 4

\begin{tabular}{|c|c|c|c|c|c|}
\hline Regressor & & Coefficient & & T-Value & \\
\hline & $\mathrm{C}$ & & -1.86 & & -5.95 \\
\hline & $\mathrm{AG}$ & & 0.71 & & 1.63 \\
\hline & $\mathrm{NF}$ & & 282.09 & & $6 . ; 31$ \\
\hline & $\mathrm{AO}$ & & 156.05 & & 5.35 \\
\hline & $\mathrm{OE}$ & & 1.86 & & 0.10 \\
\hline $\mathrm{R} 2=0.98$ & & $\begin{aligned} & \text { F-Value } \\
= & 101.2\end{aligned}$ & $\begin{array}{l}\text { DW-Stat = } \\
1.89\end{array}$ & & \\
\hline
\end{tabular}

The major findings from this estimation are as follows:

(1) The annual loan amount guaranteed bears the expected positive sign and significant at 5 percent level. This implies that loans guaranteed did impact positively to the growth of the Nigerian economy. This conforms with the view that adequate agricultural funding could lead to economic growth and hence economic development.

(2) Number of benefiting farmers bears the expected positive sign, and it is significant at the 5 percent level. This implies that it made good contribution to the economic growth of Nigeria, which agrees with increase in output as input variables increase.

(3) Annual agricultural produce also bears the expected positive sign and it is significant at 5 percent level. This implies that it made significant impact on the economic growth of Nigeria.

(4) Non-Oil Exports although bears the expected positive sign, but it is not significant at the 5 percent level. This implies that it did not make meaningful contribution to the growth of the Nigerian economy, due to perhaps no encouragement, and low export incentive in the country. The relevant finding from this study is that there is a major constraint on the intensification and development of both large and small scale farming, which agrees with the finding of Von-Prisckieke (1986) that credit is a major constraint for agricultural business. It is therefore imperative for the government to expand the agricultural credit provision to cover a larger number of farmers in the country.

The expansion of credit provision could be done in several ways including the following:

(a) Micro-finance banks with rural presence should be included in the scheme in order to take care of a number of the rural farmers. 
(b) Interest on agricultural lending should further be reduced to encourage more farmers to obtain loans for their farming enterprise, and the minimum amount that could be borrowed by farmers increased, which is presently determined by the bank giving the loan.

(c) There should be a deliberate policy by government to compel all the commercial banks to participate actively in the scheme.

It is quite obvious from the results that the provision of credit or credit availability tends to positively affect the other variables which on the long run impact positively on the growth and development of the economy.

\section{Summary and Conclusion}

The focus of this study is to empirically investigate the impact of the ACGSF in the economy of Nigeria. ACGSF is an institution set by government to ameliorate some of the problems farmers encounter in their quest for funds to carry on farming business. To facilitate the investigation relevant models and appropriate estimation techniques were employed and using annual time series data that spanned the period 1987 to 2008. The estimation results revealed that the annual loan amount guaranteed was indeed very significant and contributed positively to the growth and development of the Nigerian economy.

The findings revealed that it is imperative for government to increase the number of participating financial institutions, reduce lending rate to agriculture and other policy measures that will compel all relevant institutions to participate actively in the scheme, in order to facilitate growth and development of Nigeria. Shortage of finance is a major constraint in the agricultural sector, particularly for small holder producers.

\section{References}

[1]. Abe, S.T. (1982). Nigerian farmers and their finance problems. Bulleon Magazine. 7:4.

[2]. Adegeye, A.J. and Dittoh, J.S. (1985) Essentials of Agricultural Economics. Impact Publishers Economics Nigeria Limited, Ibadan.

[3]. Ajetombi, O. Olarinde, O.L and Ayanwale, B.A. (2003) Productivity effect of Women in Agriculture Programme, JOSTAR, 6: 57 63.

[4]. Anyanwu, J.C., Oyefusi, A. and Oaikhenan, H. (1997). The Structure of the Nigerian Economy (1960 -1999), Awka. Joance Educational Publishers Limited P. 661.

[5]. Bartelmus P. (1994), Environment Growth and Development: The concept and strategies of sustainability, Routledge, London.

[6]. Clifford, J. and Osmond, G. (1972). World Development Handbook. Charles Knight \& Co. Ltd. London.

[7]. Hamnin, D.R. (1980), Managing Growth in the 1980s Towards a New Economics. Draeg Publishers, New York.

[8]. James L. and Miller, C. (2010). Agricultural value chain finance, tools and Lessons; Practical Action Publishing Bourton Hall, UK.

[9]. Jumper, R.S. Thamas, L.B. and Ralstir, A.B. (1984). Economic Growth and Disparities World View, Practice-Hall, Inc. England Cliffs, NJ.

[10]. Kuznets, S. (1973). Modern Economic Growth Findings and Reflection: The American Economic Review. June 1973

[11]. Niloy, B., Edmond, M.H and Demise, R.O. (2003). Public Expenditure and Economic Growth. A disaggregated Analysis for Developing Countries, JEL Puublication.

[12]. Prokopenko, J. (1972). "Productivity Management. A Practical Handbook" International Labour Organization, Geneva

[13]. Todaro, P.M. \& Smith, C. (2003). Economic Development, $8^{\text {th }}$ edition, Pearson Education Inc., Delhi, India 829 p.

[14]. Von-Pischike, J.D. (1991) A critical survey of approaches to the role of credit in small holder development. Discussion paper. Institute for development studies, University of Narobi. 